\title{
The interpretation of the verbal probability expressions used in the IFRS - The differences observed between Polish and British accounting professionals
}

\author{
Katarzyna Kolesnik ${ }^{\mathrm{a}}$, Sylwia Silska-Gembka ${ }^{\mathrm{a}}$ and Jerzy Gierusz ${ }^{\mathrm{a}, 1}$ \\ ${ }^{a}$ University of Gdansk, Poland
}

\begin{abstract}
Research Question: Do Polish and British accounting professionals interpret verbal probability expressions (VPEs) differently when presented with identical excerpts from IFRS? Motivation: Our research has been motivated by the ongoing debate of consistent interpretation of VPEs. The major difficulty in the interpretation of these terms is the imperative for the accountants to express their individual subjective judgements. Previous research shows that these expressions may have low communication efficiency (Simon, 2002) as they give way to 'wide variations in interpretation' (Chesley, 1986: 196). The lack of consistency in the interpretation of VPEs may limit the usefulness of the financial statements prepared on their basis (Simon, 2002). Idea: We examine the interpretational differences between Poles and the British. We also survey whether the principle of prudence will impact the interpretation manner of the Polish and the British accounting professionals. Data: For the purpose of our study we distributed a questionnaire. 332 questionnaires from Poland and 75 questionnaires from the UK included answers that were subject to the analysis. Tools: We asked a sample of professional accountants from Poland and the UK to interpret the "in context" VPEs used in IFRS establishing the threshold for recognition of various accounting elements. Findings: Our results show that there are differences in the manner the Poles and the British interpret VPEs. Additionally, we indicate that the Polish accountants' attachment to the prudence principle affects their manner of interpretation. However, we were not able to state whether this
\end{abstract}

${ }^{1}$ Corresponding authors: Department of Accounting, University of Gdansk; Armii Krajowej Str. 101, 81-824 Sopot; tel. (+48) 52314 23; email addresses: katarzyna.kolesnik@ug.edu.pl; sylwiasilska@wp.pl; rachunkowosc@wzr.pl 
principle would not affect the level of probability assigned by the British accountants. Contribution: Our paper provides the first comparative results for Poland and the UK, in terms of surveying professional judgement under with relation to the IFRS.

Keywords: IFRS; interpretation; professional judgement; verbal probability expressions

\section{JEL codes: M41}

\section{Introduction}

Comparability of financial information is the major goal for both the EU Commission as well as for the International Accounting Standards Board. Nonetheless, having a common set of financial reporting standards, such as the IFRS, is a necessary, but not a sufficient enough condition to ensure the comparability of global financial reporting. To ensure comparability, consistent application of IFRS across all jurisdictions must be achieved. One of the potential risks associated with inconsistencies, which may still continue to exist in the IFRS era, is the interpretation of the terms related to uncertainty occurring in the IFRS.

IFRS include a number of verbal probability expressions (VPEs) such as probable, expected and remote, which are used to determine recognition, measurement and disclosure of various items in financial statements. Following the IAS 37, paragraph 14 , provision is recognized when 'it is probable that an outflow of resources embodying economic benefits will be required to settle the obligation'.

The major difficulty in the interpretation of VPEs is the imperative for the accountants to express their individual subjective judgements. As Chesley emphasizes (1986: 196), the commonly-used expression probable gives way to 'wide variations in interpretation'. The variability of the interpretation accountants and auditors assign to such terms and expressions may result from their ambiguity (Chesley, 1986) and/or from the fact that they are not very distinct (Houghton \& Walawski, 1992). Interpretation may also be influenced by the context in which these expressions are used (Doupnik \& Richter, 2004), the interpreting accountant's experience (Teixeira \& Silva, 2009), the translation (Baskerville \& Evans, 2011) and many other factors, such as the country of origin. In its present condition, the lack of consistency in the interpretation of VPEs results in a lack of consistency in the interpretation of specific accounting standards and their application (Amer et al., 1994), which, in turn, limits the usefulness of the financial statements prepared on their basis (Simon, 2002). 
Taking into account the fact that these expressions are used to determine recognition, measurement, and disclosure of each item in a financial statement, it can be stated that they have impact on the image of the entity presented in such a statement. Given the omnipresence of these expressions in the IFRS and the importance of the issues they describe, the manner of their presentation calls for research involving accounting systems.

This paper investigates interpretation of VPEs, both in Poland and the in UK, where distinctive linguistic differences and contrasting accounting traditions exist. There is a clear dissimilarity between the two countries we have chosen for our study. Poland is considered an example of the Continental European model of accounting (Surdykowska, 1999; Jaruga, 2002; Winiarska, 2009), whereas the UK is a clear example of the Anglo-Saxon one (Doupnik \& Perera, 2009). Despite the implementation of the IFRS, Poland, in contrast to the UK, is still heavily dominated by the principle of prudence, and by taxes (Kabalski, 2012).

Taking the above into consideration, our paper addresses the question of whether Polish and British accounting professionals interpret VPEs differently when presented with identical excerpts from IFRS. We hypothesize that differences in the interpretation will occur. Considering the Polish accounting professionals' attachment to the principle of prudence and their British counterparts' attachment to the principle of true and fair view (TFV), we also hypothesize that the prudence principle will have significant impact on the Poles' interpretation of VPEs. By contrast, we assume that this principle will have no impact on the interpretation presented by the British accounting professionals.

We contribute to the literature on the subject by documenting the significant differences in the probabilities assigned to the English expressions of probability and their various translations into Polish existent between the Polish and British survey participants. In addition, we find that Poles tend to be more influenced by the prudence principle when interpreting verbal probability expressions, relative to the British accounting professionals. Our paper contributes to the findings of prior studies, by providing the first comparative results for Poland and the UK, in terms of surveying professional judgement under with relation to the IFRS. To our best knowledge, no research has been carried out on comparison of the interpretational differences existing among European countries. Only one research, carried out by Doupnik and Richter's (2003), presented comparative analyses in the European context: German-speaking countries (Germany, Austria, the German-speaking Switzerland). However, the verbal probability expressions found in the IFRS were presented 'in isolation', without the context they are likely to be used in. What is more, most of the studies neglected the Central Eastern Europe countries. Poland, similarly to other transition economies, offers an interesting, yet a challenging area for accounting studies, because it is a post-communist economy and thus its 
institutional orientation is significantly different from the Anglo-Saxon origins of the IFRS.

This paper provides a valuable insight into the consistent application of the IFRS. Our study should provide some tentative implications on the VPEs in the IFRS to be considered by the Standard Setters.

The paper is structured as follows: it begins with a development of the hypothesis, followed by a description of the methodology and the results. The final section concludes the study.

\section{Previous research and the issue of using the verbal probability expressions (VPEs) occurring in the accounting standards}

The basic issue involving language is the use of the terms describing plausibility, such as likely or probable, because they are quite ambiguous. A term is regarded as equivocal, if it can be understood in at least two different ways; i.e. it has more than one meaning. However, each of these meanings can be very precise. An example in Polish can be the word pokój, which means either a room or the opposite of war (peace). In terms of VPEs, the problem seems to be more complex. These expressions must not be recognized and understood as synonyms, because they describe a probability hierarchy (e.g. 40\%-60\%) (McGlone \& Reed, 1998: 723). What is more, it has been found that people understand those terms not only as descriptions of a probability scale, but as an extent of the obviousness embedded in such a probability as well (Wallsten et al., 1986). Thus, communication using VPEs ceases to be very precise. Ironically, however, in situations when information concerning a probability of some event's occurrence is transmitted, people tend to use these terms, rather than more precise numerical expressions (Zwick, 1987). The use of numerical expressions is regarded as confusing, because, as a rule, judgement and predictions that are associated with description of probability, in a situation a person is not sure of, rarely are precise (Wallsten et al., 1986).

As Amer et al. (1994: 134) state, accountants and auditors also prefer verbal expressions rather than numerical expression of probability: 'the outcomes of many accounting events are often difficult to predict and probability expressions are used to communicate and measure inherent uncertainty'. However, the use of those expressions causes a number of significant problems, since these expressions are used to communicate vital decisions. There is a multitude of words expressing the extent of probability, and it would be difficult to come up with a glossary containing all such terms. What is more, people tend to understand single words differently (Hamm, 1991). 
Despite the multiplicity of the difficulties associated with the use of VPEs, these expressions are fairly common in the IFRS. However, the respective studies carried out so far have mainly dealt with interpretation of the VPEs in the Financial Accounting Standards (SFAS) No. 5 Accounting for Contingencies, published by the FASB (Jiambalvo \& Wilner, 1985; Harrison \& Tomassini, 1989; Reimers, 1992; Amer et al., 1995; Nelson \& Kinney, 1997; Aharony \& Dotan, 2004; Capriotti \& Waldrup, 2005). For example, Jiambalvo and Wilner (1985) provided empirical evidence on interpreting the language of uncertainty, based on auditors' evaluations of contingent claims. Reimers (1992) used specific terms from the SFAS No. 5 to assess whether the auditors' and managers' interpretations were in agreement. The study conducted by Aharony and Dotan (2004) investigated whether financial statement users interpret the FASB disclosure guidelines more conservatively than the preparers of the financial statement.

Several related papers focused on the interpretation of many expressions of uncertainty occurring in various national accounting standards (Amer et al., 1994; Laswad \& Mak, 1997; Simon, 2002; Han et al., 2016). The expressions used in the research by Laswad and Mak (1997) included the phrases expressing uncertainty that are used in the US, New Zealand, Australia, Canada, UK as well as in the international accounting standards issued by the IASC, while the study by Amer et $a l$. included mainly the US standards. Simon (2002) analyzed interpretation of the expressions of probability used in the UK standards while Han et al. (2016) examined those used in the Chinese Accounting Standards. On the other hand, the issue of interpreting the probability expressions occurring only in the IFRS was undertaken by Doupnik and Richter (2003, 2004), Doupnik and Riccio (2006), Teixeira and Silva (2009), Salleh et al. (2011a, 2011b), Chand et al. (2012), Hu et al. (2013), Huerta et al. (2016) and Seo and Thomson (2016). Doupnik and Richter (2004) examined how national culture affects interpretation of VPEs. They only analyzed the issue with respect to the impact that conservatism has on the way professional accountants representing Anglo and German culture interpret these terms, while Doupnik and Riccio (2006) extended this research to a previously unexamined Latin cultural area by examining the impact of secrecy on the interpretation of these expressions.

Moreover, Chand et al. (2012) and Hu et al. (2013) focused on the impact national culture has on judgment when interpreting selected IFRSs containing expressions of uncertainty. The sample in both studies consisted of Australian and Chinese accounting students residing in Australia. To extend the previous cross-cultural research, Hu et al. (2013) also analyzed whether cultural values of individuals could change due to acculturation and the acquired accounting education as well as measured the potential influence of those values on the accounting judgment. The studies carried out by Salleh et al. (2011a, 2011b) addressed the issue of the differences in interpretation of accounting standards, by examining the differences in VPE interpretation that exist between native Chinese-speaking and the native 
English-speaking accounting students in UK universities. Huerta et al. (2016) compared the interpretation manner of accounting students from two distinct cultures (Americans and Mexicans) and of accounting students who share both cultures (Mexican-Americans), to investigate whether bicultural individuals are influenced by the language they use. Seo and Thomson (2016) focused on the differences in the interpretation of VPEs by financial statement preparers and auditors from Korea and Australia. They also examined whether the translations of these terms are consistent with the original expressions.

Previous research focused on the attempts to determine the extent to which the respondents associate particular expressions with the probability expressed in numbers (most commonly on a $0-100 \%$ scale). The significant differences in the assessment of the probability assigned to VPEs allow a conclusion that the words analyzed are interpreted differently by the subjects. For this reason, the respondents were asked to interpret single words exclusively, 'in isolation', without the context they are likely to be used in (Chesley 1986; Reimers, 1992; Laswad \& Mak, 1997; Simon, 2002; Doupnik \& Richter, 2003; Teixeira \& Silva, 2009; Seo \& Thomson, 2016) or to interpret these words in context. In such case, the expressions are presented in reference to a specific situation, mentioned in the test material, that can be encountered by the respondents in their work (Jiambalvo \& Wilner, 1985; Harrison \& Tomassini, 1989; Amer et al., 1994, 1995; Capriotti \& Waldrup, 2005). They might also be presented with excerpts from accounting standards containing such expressions (Doupnik \& Richter, 2004; Doupnik \& Riccio, 2006; Teixeira \& Silva, 2009, Salleh et al., 2011a, 2011b; Chand et al., 2012; Hu et al., 2013; Seo \& Thomson, 2016).

Existing studies - contrary to our research - address the issue of differences in VPE interpretation existing mainly among one group of subjects: accounting students (Chesley, 1986; Davidson \& Chrisman, 1993; Chand et al., 2012), auditors (Jiambalvo \& Wilner, 1985; Harrison \& Tomassini, 1989; Reimers, 1992; Amer et al., 1994, 1995; Harrison \& Tomassini, 1989; Teixeira \& Silva, 2009), commercial loan officers (Capriotti \& Waldrup, 2005) and the setters of the accounting standards (Laswad \& Mak, 1997). In our study, the reference group was composed of finance managers, chief accountants and auditors from both Poland and the UK.

The studies carried out so far indicate that interpretation of expressions of uncertainty causes problems, partly due to the fact that many of those expressions are understood as synonyms, since they have been assigned the same grade of probability. This applies to such terms as e.g. probable, which is interpreted as likely (Reimers, 1992; Laswad \& Mak 1997; Doupnik \& Richter, 2003), reasonably assured understood as reasonably certain (Laswad \& Mak, 1997), or high probability regarded as expected (Reimers, 1992). 
Some terms, such as very likely and less likely, very likely and very unlikely, or probable and improbable are not respectively complementary, since the numerical probability of mirror-image pairs of terms do not add up to $100 \%$ (Chand et al., 2012).

The major difficulty in the interpretation of the above-mentioned expressions, however, is the imperative for accountants to use their individual subjective judgement. Moreover, when assessing the probability of occurrence of an event, while such probability is additionally expressed through VPEs, subjective judgement is required:

while specifying which probability threshold describes a given expression;

and

while analyzing facts and circumstances determining that the probability threshold has been reached.

To name some examples: following the IAS 37, paragraph 14 , recognition of a provision in a financial statement occurs when 'it is probable that an outflow of resources embodying economic benefits will be required to settle the obligation'. Thus, an accountant must be able to assess, in the first place, whether the expression 'it is probable' means a probability over $50 \%$ or perhaps over $60 \%$, and then decide whether the threshold has been reached in that case. This also means that different interpretation of the same expression by different accountants - even under identical circumstances - might lead to different decisions regarding recognition of a given item in a financial statement. This is supported by a survey carried out by Jiambalvo and Wilner (1985), which was aimed at answering the question of whether disclosure judgements are consistent with the probability ranges of individual auditors. Those authors' findings clearly indicate that incoherence in the probability assessments attributed to particular expressions was clearly responsible for the differences in the decisions concerning disclosure.

Culture is likely to be one of the main causes of the differences in VPE interpretation, due to its alleged influence on the cognitive process involved in determining and understanding probability, as formulated by Philips (1970). The studies conducted by Wright and Philips (1980) supported this opinion. The numerical probabilities assessed by Asians were less realistic and more extreme than those assessed by the British. The Asians were found to have a less finely differentiated view of uncertainty than the British. Other researchers, who conducted cross-national studies in the accounting domain (Doupnik \& Richter, 2003, 2004; Doupnik \& Riccio, 2006; Chand et al., 2012; Hu et al., 2013), also noticed that culture is a significant factor affecting interpretation of these expressions. 
The manner in which VPEs are interpreted also depends on the language in which a given phrase is expressed. According to Huerta et al. (2016), the bilingual Mexicans living in the US interpreted the Spanish expressions in a similar way as the Mexicans living in Mexico. On the other hand, when asked to interpret the same expressions in English, their answers were close to those given by the Americans.

A study carried out in Canada by Davidson and Chrisman (1993), testing Anglophone and Francophone accounting students, showed that the expressions of uncertainty, the English terms and their French counterparts, were not equal. Their survey failed to determine, however, whether those differences were due to translation from English into French or because of a different understanding of the core meaning of particular words on the part of the individuals speaking different languages.

Interpretation of the terms describing uncertainty constitutes a potentially difficult subject within the area of IFRS translation (Baskerville \& Evans, 2011). Moreover, Doupnik and Richter (2003) stated that translation from English into German has specific impact on the interpretation of the expressions denoting the highest and the least probability. On the other hand, Hellman, Perera and Patel (2010) believe that the significant discrepancies existing between the English and the German versions of the IFRS wording hinder a uniform application of the accounting standards. Also, the research conducted by Seo and Thomson (2016) indicates that the Korean translation of the original English expressions may alter their interpretation.

According to both accounting and non-accounting research, demographic factors are also responsible for the differences in interpretation of VPEs . Han et al. (2016) show that gender can affect the numerical thresholds that auditors assign to expressions of uncertainty. Other studies also provide evidence that these expressions are interpreted differently by different occupational groups (Laswad \& Mak, 1997; Amer et al., 1995).

If accountants' opinions on the interpretation of these expressions differ, it means that the regulations containing such expressions are not explicit. As such, the accountants' opinions on the application of the same accounting regulations vary (Amer et al., 1994), which, in turn, reduces the usefullness and the comparability of financial statements (Simon, 2002), thus defeating the primary aim of the harmonization of accounting.

\section{Hypothesis development}

It has been argued that the national accounting regimes that are binding in various countries differ remarkably in terms of the accounting rules and practices (Nobes, 1998; Jaggi \& Low, 2000; Schultz \& Lopez, 2001; Richardson, 2007; 
Ghio \& Verona, 2015; Carneiro et al., 2017). According to Nobes (2006), the country-specific factors identified in the past may still be relevant for IFRS consolidated reporting. More specifically, a national accounting tradition may have influence on the accountants and the auditors and may result in different individual judgements, even though the same set of rules is applied. Under many circumstances, the IFRS provide broad guiding principles that require a high level of skill and judgement in their application (Vellam, 2004). Thus, proper judgement is particularly important in financial reporting.

In terms of Poland and the UK, there is a number of factors that may influence accountants and result in differences in judgement. Firstly, Poland has long been dominated by the tradition of tax rules in accounting regulations. Soon after the economic transition took place, the legal basis for the first accounting directive of the Ministry of Finance (1991) was formed by the tax law. Transactions had to be settled in such a way that would be consistent with the fiscal law. The fiscal system has been separated from financial accounting since 1994, when the first Accounting Act was introduced. However, the entities that have been given a choice, still may apply the accounting practices reflecting the tax policy. Vellam (2004) examined the practical problems that Polish accountants face in their attempt to adopt the IASorientated framework. All the accountants who were interviewed indicated the tax authorities as the primary recipients of the financial information published. Moreover, the accountants pointed out to the lack of trust on the part of the tax authorities, who perceived accountants as tax cheaters and 'the onus was on them to prove otherwise' (Vellam, 2004: 162). Based on her findings, Vellam (2004: 163) confirms that 'the relationship with the tax authorities is strained and deeply mistrustful. The focus on tax issues frequently overshadows any other economic considerations and prevents the adoption of a principle-based system of accounting'. Thus, it may affect the interpretation and application of the IFRS (Kabalski, 2012). In contrast to Poland, financial accounts in the UK are mostly free of taxation influences (Roberts et al., 2008).

Secondly, the Polish tradition exhibits a more codified approach to accounting regulations than the conventions of the common law (Jaruga, 1993; Surdykowska, 1999), which constitutes the basis of accountancy in the UK (Hung \& Subramanyam, 2007). Practical implementation of principle-based accounting in Poland is likely to be more difficult, due to the rule-based orientation rooted in the Roman Law tradition, which is inconsistent with the IFRS spirit. According to Polish accountants, compliance with the legal requirements is one of the primary factors influencing accounting practices, and little attention is paid to the need of the investors (Vellam, 2004).

Thirdly, Poland and the UK have been classified as members of two distinctly different cultural areas (Hofstede, 2010). The national cultural values identified by Hofstede differ significantly for Poland and the UK, especially in terms of the degree 
of avoidance of uncertainty (Gierusz et al., 2014). Hofstede says (2007: 270): 'the degree of uncertainty avoidance that is typical for a given country, would influence the accounting manner in this country' [our own translation]. These values may affect accountants at an individual level and therefore may also be relevant in their judgements (Wehrfritz \& Haller, 2014).

Fourth, a language predisposes its speakers to particular ways of thinking and therefore speakers of different languages also perceive and interpret accounting concepts differently (Evans, 2004). Moreover, the research conducted by Huerta et al. (2016) shows that the manner in which VPEs are interpreted might also depend on the language used to denote a given expression. Following Hall's theory (1976), English is classified as a low-context language (Copeland \& Griggs, 1985), whereas Polish is a high-context one (Zieba, 2008). Low-context languages are more precise than high-context ones (Huerta et al., 2016). These differences lead to difficulties in translating the IFRS sufficiently into Polish. As Doupnik and Richter (2003) and Hellman et al. (2010) state, a given translation from English is very likely to have significant impact on the interpretation of the phrases expressing probability. This may cause alternative accounting practices (Nobes, 2006).

Based on the above discussion, we posit that:

H1: Polish accounting professionals interpret the VPEs used in IFRS differently than their British counterparts.

The prudence principle has been present in Polish accounting since 1934, due to the German influences that entered the field when the Polish Commercial Code, based on the German one, was implemented (Helin, 2005).

During the communist era, accounting was aimed at providing the information that was required by central planners, with 'no place for the concept of fair presentation nor for the TFV principle' (Lesko, 2007: 57). The TFV principle (the true and fair view) emerged in 1991 when the Regulation on Accounting Principles, presenting a number of the rules included in the 4th EU Directive, was introduced. The Regulation did not incorporate the principle of prudence directly, yet it was clearly indicated in the guidelines to the methods of asset and liability valuation (Kabalski, 2012).

The new Accounting Act adopted in 1994 incorporated the TFV, at the same time emphasizing that all transactions must be disclosed with prudence, so as not to overstate the financial result. Thus, the prudence principle and the method of cost valuation remained the dominant concepts throughout the Act and in accounting practice as well (Lesko, 2007). 
In order to bring Polish accounting closer to the IAS, the Accounting Act of 1994 was amended in 2000, decreasing the importance of the prudence principle. As Kosmala (2005: 583) states, 'under the new Act, more judgement-based TFV construct de jure replaces the TFV enveloped in a prudence (as under the 1994 framework)'. However, studies show that Polish accountants still 'deem prudence the most important principle of evaluation in accountancy and consider it a realistic image of the company rather than pessimistic' (Honko, 2008: 265).

In the UK, the TFV is most likely to be the commonest solution applied in accounting, by having a major impact on the valuation and on presentation of information in financial statements. The principle of prudence is regarded as one of little importance. It is commonly believed that a prudential approach to resource and flow valuation might infringe the principle of presenting true information in the statements (Hung \& Subramanyam, 2007).

Prudence (conservatism) is defined as a 'differential verifiability' that is required for recognition of profits, in comparison to losses (Watts, 2002). As Laughlin and Gray (1988) state, 'the prudence or conservatism convention refers to the accountant's tendency to be cautious - cautious almost to the point of pessimism'. The level of conservatism shared by accountants might affect their interpretation of the VPEs in the IFRS, since they are used to establish the threshold for recognition of various items (gains, assets, losses, liabilities) (Doupnik \& Richter, 2004).

Based on above discussion, we posit that the principle of prudence affects the probability assigned to the expressions by Polish accounting professionals, therefore they need greater certainty to recognize profit than to recognize loss. As such, they would apply a higher probability threshold to the items resulting in an increase of the financial result than to the items resulting in its decrease. On the other hand, we posit that this principle does not have any impact on the probability assigned by British accounting professionals, therefore they need greater certainty to recognize loss than to recognize profit. As such, they would apply a lesser probability threshold to the items resulting in an increase of the financial result than to the items resulting in its decrease.

This leads to the following hypotheses:

H2: Polish accounting professionals assign a higher numerical degree of probability to the VPEs in the IFRS when it is used as a threshold for recognizing the items that increase the financial result than when used to recognize the items that decrease the financial result.

H22: British accounting professionals assign a lesser numerical degree of probability to the VPEs in the IFRS when it is used as a threshold for recognizing 
the items that increase the financial result than when used to recognize the items that decrease the financial result.

\section{Research methodology}

For the purpose of our study, a questionnaire was distributed among the research participants, which included eleven excerpts selected from the IFRS, containing the following VPEs: probable, not probable, reasonable assurance, and remote. The sample composed of professional accountants, who were asked to interpret these expressions and establish a threshold for recognition of various accounting elements. After reading each paragraph, the respondents were asked to answer the following question: 'The expression probable, in this context, corresponds to a probability greater than what percentage?' We used a scale of 0 to 100 percent for each VPE, where 100 percent referred to absolute certainty and 0 to impossibility. Such approach is often used in accounting research (Doupnik \& Richter, 2004; Doupnik \& Riccio, 2006; Teixeira \& Silva, 2009; Salleh et al., 2011a, 2011b; Chand et al, 2012).

The reference group comprised finance managers, chief accountants and auditors, who, in their professional work, are responsible for the shape of the financial statements they prepare, thus, they frequently must refer to their professional judgement.

In Poland, the questionnaire was mailed to accountants and auditors, who were selected during obligatory training courses offered by the National Chamber of Auditors (Krajowa Izba Bieglych Rewidentow). Excerpts from the official Polish translation of the IAS were used. Paper copies of the questionnaire, along with an addressed return stamped envelope, were mailed to randomly selected training centers. A total of 984 questionnaires were mailed out. A total of 351 questionnaires were returned, 332 of which included answers that were subject to the analysis. The analysis did not cover incomplete questionnaires nor those that contained formal errors.

The English version of the questionnaire was e-mailed to members of the ACCA and the ICAEW, who work in the accounting and auditing companies randomly selected from the Register of Statutory Auditors (www.auditregister.org.uk). Ultimately, 995 questionnaires reached the target group. 163 questionnaires were returned, however, only 75 were fit for the analysis.

Since the VPEs analyzed are used in individual paragraphs of the IFRS in different contexts, for the purpose of our analysis, the IAS excerpts used in the questionnaire were divided into three groups, depending on the context a given expression was 
The Interpretation of the Verbal Probability Expressions Used in the IFRS - The Differences observed between Polish and British Accounting Professionals

used in, i.e.: 1) recognition of assets or measurement of the items increasing the financial result, 2) recognition of liabilities or measurement of the items decreasing the financial result, and 3) disclosures in financial statements.

While the VPEs analyzed are used for measurements of the items resulting in both an increase and a decrease of the financial result, the respondents' approach to the prudence principle is expected to affect the manner of their interpretation. The point estimates of the expressions of probability were summarized using the statistical mean and the standard deviation. To determine whether the extent of a probability that the events resulting in a financial result increase differs substantially from the extent of a probability of events resulting in its decrease, the Wilcoxon signed rank test was applied.

\section{Results}

\subsection{Responses}

Table 1 presents the response rates and the respondent profiles.

Table 1. The population and sample

\begin{tabular}{|c|c|c|c|c|}
\hline \multirow{2}{*}{ Subject } & \multicolumn{2}{|c|}{ Number of persons } & \multicolumn{2}{|c|}{ No data } \\
\hline & Poland & The UK & Poland & The UK \\
\hline Questionnaires mailed: & 984 & 995 & & \\
\hline Study sample Total: & 332 & 75 & - & - \\
\hline Response rate: & $33.74 \%$ & $7.54 \%$ & - & - \\
\hline \multicolumn{5}{|c|}{ Respondent Profile } \\
\hline Gender: & & & 2 & 12 \\
\hline$-\quad$ female & 236 & 9 & & \\
\hline - $\quad$ male & 94 & 54 & & \\
\hline Occupation: & & & 14 & 22 \\
\hline - $\quad$ auditor/chartered accountant & 183 & 36 & & \\
\hline $\begin{array}{l}\text { - financial director, chief } \\
\text { accountant }\end{array}$ & 60 & 7 & & \\
\hline - $\quad$ other* & 75 & 10 & & \\
\hline ACCA qualification & 37 & 11 & 23 & 24 \\
\hline $\begin{array}{l}\text { Professional experience in a } \\
\text { multinational company }\end{array}$ & 80 & 8 & 21 & 21 \\
\hline Application of the IFRS in their work: & & & 12 & 21 \\
\hline$-\quad$ regularly & 61 & 17 & & \\
\hline - occasionally & 190 & 25 & & \\
\hline - never & 69 & 12 & & \\
\hline
\end{tabular}

*This group includes lower-rank accounting employees. 
The high response rate obtained in Poland (33.74\%) compared to that in the UK (7.54\%), probably can be attributed to the fact that filling out a paper copy of the questionnaire, during a training course, is less burdensome than filling out its electronic version during work time.

Unlike in the UK, majority of the respondents in Poland were females. The reason for this, is that in Poland women are more likely to become accountants, because accounting is viewed as a feminine profession (Kabalski \& Szwajcar, 2015). The subjects were aged between 21 and 85 (in Poland) and from 24 to 72 (in the UK). The average age for the Polish respondents was $53 \mathrm{y} / \mathrm{o}$, while, on average, at the time of the survey, they had been working as accountants or auditors for 25.43 years (i.e. not shorter than 2 years and maximum 66 years). Among the UK respondents, the average age was $49.4 \mathrm{y} / \mathrm{o}$ and the average duration of employment as accountants or auditors was 26 years (not shorter than 1 year and maximum 50 years). In Poland, over $55 \%$ of the respondents were auditors, while over $11 \%$ of the auditors had ACCA qualifications. In the UK, these figures were $48 \%$ and over $14 \%$ respectively. Over $24 \%$ of the Polish respondents worked for international corporations, while in the UK over $10 \%$ of the respondents were employed by international companies. The average length of the respondents' employment in such corporations was 8.63 and 7.44 years for Poland and UK respectively. Over half of the Polish respondents applied the IFRS occasionally in their work, while for the UK respondents the percentage was over $33 \%$.

We carried out the Mann-Whitney U test, the Kruskal-Wallis test and the Spearman's rank correlation to determine whether gender, the position held, professional experience in a multinational corporation, the ACCA qualifications and the frequency of the IFRS application at work affected the respondents' interpretation of the VPEs. For almost all the IAS paragraphs used in the questionnaire, the connection between the assessment of probability and the age and professional experience (expressed in years) was not statistically significant. The analyses showed that only for the IAS 16, paragraph 7 (both in Poland and in the UK) as well as for the IAS 18 paragraph 22 (for the UK only) older and more experienced respondents assigned the highest extent of probability to the standards in question $(p<0.05)$. Only in the UK, the frequency of the IFRS application at work as well as the fact of having ACCA qualifications affected the assessment of probability exclusively for the IAS 11 paragraph 23 , while the occupation held affected interpretation of the IAS 18 paragraph $22(\mathrm{p}<0.05)$ singularly. None of the remaining factors had impact on the assessment of probability, both in Poland and in the UK. Considering the fact that each feature examined determined the extent of probability for one accounting standard only, it can be assumed that the results obtained did not differ much for the factors under examination. However, the uneven sample sizes of the respondents reacting to one tested factor may have also affected the result. 


\subsection{Testing H1}

Table 2 presents the results regarding the interpretation of the VPEs analyzed.

With respect to the standards under analysis, the English expression is probable has a number of corresponding phrases in Polish: istnieje prawdopodobieństwo, jest prawdopodobne, and prawdopodobne jest, denotations of which are equal and convey the same literal meaning as the original expression in English. However, the

Polish translation of the expression reasonable assurance, occurring in the IAS 20 paragraph 7 , is translated as nie istnieje wystarczajaca pewność, which translated back into English literally means no reasonable assurance. Although the overall meaning of this standard is the same, the Polish translation appears to be a contradiction of the phrase used in the original version in English.

Moreover, in the IAS 36 paragraph 12, the English phrase are expected has been translated to mean the same as is probable (prawdopodobne jest). Yet, according to research findings (Doupnik \& Richter, 2004; Reimers, 1992), the phrase are expected carries a higher level of probability than the expression is probable. Doupnik and Richter (2004) also indicated that American accountants, for instance, assigned $80.16 \%$ probability to the expression expected and $71.37 \%$ to the expression probable. Also, Reimers (1992), who, among others, examined the interpretation manner of American auditors, found that $80 \%-85.8 \%$ probability was assigned to the expression expected, and $66.2 \%-77.6 \%$ to probable respectively.

Our findings show that statistically significant differences in determining the level of probability by accounting professionals in Poland and in the UK were noted in six out of the twelve analyzed IAS excerpts (Table 2). An exception is the IAS 37 paragraph 28, for which the Polish subjects assigned a significantly lower level of probability than the British ones. The most significant differences were recorded for the expressions the Polish translation of which did not convey the very meaning of the phrases used in the original - English - version of the standards (IAS 20/7 and IAS 36/12).

Taking the above into account, the first hypothesis, assuming that Polish accounting professionals interpret the VPEs contained in the IFRS differently, in comparison to their British counterparts, can be supported partially.

\subsection{Testing $\mathbf{H} 2_{1}$}

To test $\mathrm{H} 2{ }_{1}$, a comparison of the mean of the level of probability assigned to the Polish equivalents of the English expression probable, which is used in the IAS excerpts under examination and resulted in measurement of the items increasing or decreasing the financial result, was conducted (Table 3 ). 
The Polish subjects indicated a higher level of probability for the items resulting in an increase in the financial result than for the items resulting in a decrease. These differences occurred in all the comparison analyses carried out and were statistically significant. Thus, we are in the position to state that the principle of prudence affects the level of the probability assigned by the Poles to the expressions under analysis.

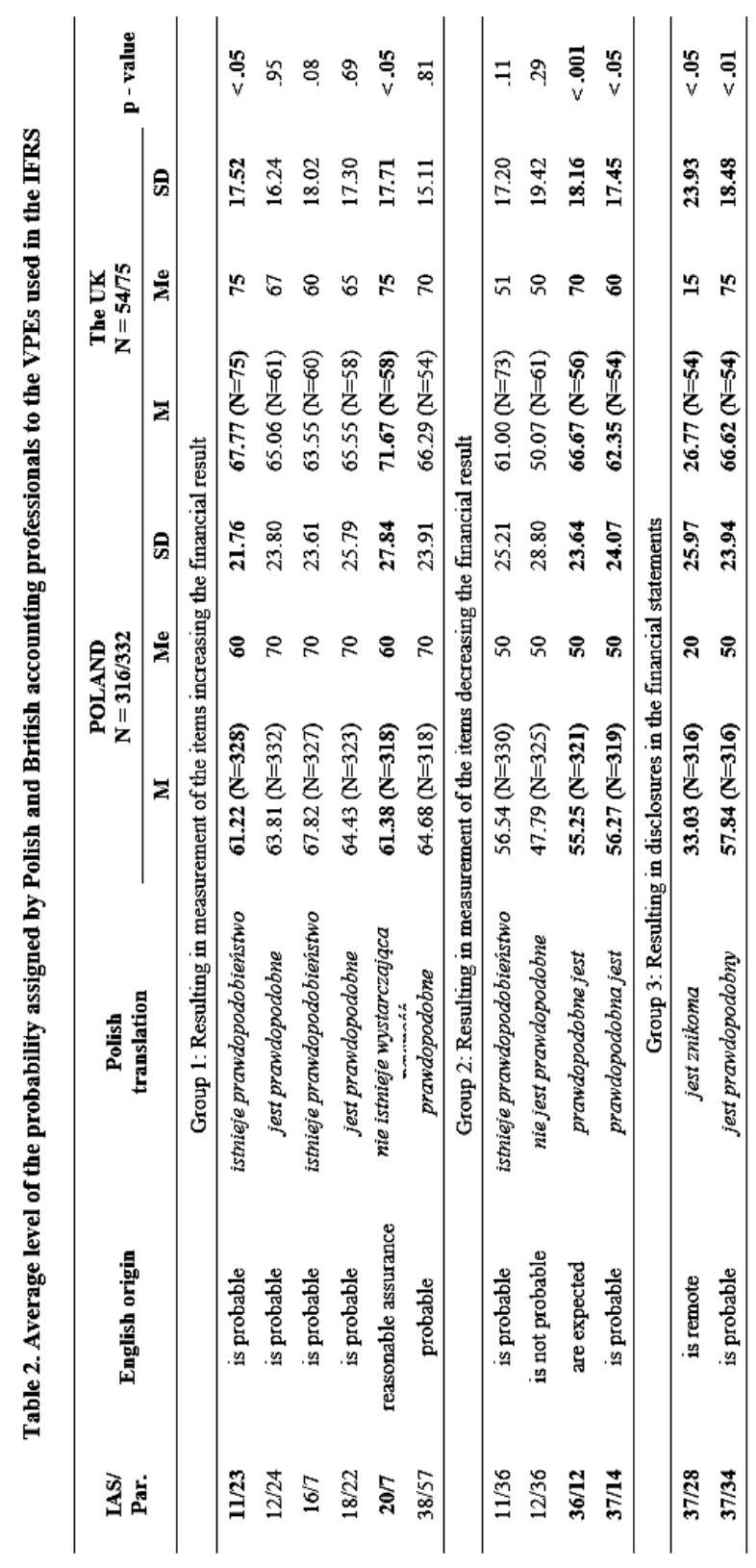


The Interpretation of the Verbal Probability Expressions Used in the IFRS - The Differences observed between Polish and British Accounting Professionals

Table 3. Comparison of the mean of the level of the probability assigned by Polish accounting professionals to the expression probable, resulting in an increase and a decrease in the financial result

\begin{tabular}{|c|c|c|c|c|c|}
\hline \multicolumn{3}{|c|}{$\begin{array}{c}\text { Comparison of the average probability assigned to the } \\
\text { expressions used in the IASs }\end{array}$} & \multirow[b]{2}{*}{$\begin{array}{l}\text { Consistency } \\
\text { with our } \\
\text { expectations }\end{array}$} & \multirow[b]{2}{*}{$\mathbf{z}$} & \multirow[b]{2}{*}{$\begin{array}{c}\text { p- } \\
\text { value }\end{array}$} \\
\hline $\begin{array}{c}\text { Resulting in } \\
\text { measurement of the } \\
\text { items increasing the } \\
\text { financial result }\end{array}$ & & $\begin{array}{l}\text { Resulting in } \\
\text { measurement of the } \\
\text { items decreasing the } \\
\text { financial result }\end{array}$ & & & \\
\hline $11 / 23$ & $>$ & $11 / 36$ & yes & -3.64 & .000 \\
\hline $12 / 24$ & $>$ & $11 / 36$ & yes & -4.26 & .000 \\
\hline $16 / 7$ & $>$ & $11 / 36$ & yes & -6.98 & .000 \\
\hline $18 / 22$ & $>$ & $11 / 36$ & yes & -5.14 & .000 \\
\hline $38 / 57$ & $>$ & $11 / 36$ & yes & -5.22 & .000 \\
\hline $11 / 23$ & $>$ & $36 / 12$ & yes & -4.12 & .000 \\
\hline $12 / 24$ & $>$ & $36 / 12$ & yes & -4.80 & .000 \\
\hline $16 / 7$ & $>$ & $36 / 12$ & yes & -7.26 & .000 \\
\hline $18 / 22$ & $>$ & $36 / 12$ & yes & -6.55 & .000 \\
\hline $38 / 57$ & $>$ & $36 / 12$ & yes & -6.56 & .000 \\
\hline $11 / 23$ & $>$ & $37 / 14$ & yes & -3.53 & .000 \\
\hline $12 / 24$ & $>$ & $37 / 14$ & yes & -4.98 & .000 \\
\hline $16 / 7$ & $>$ & $37 / 14$ & yes & -6.68 & .000 \\
\hline $18 / 22$ & $>$ & $37 / 14$ & yes & -5.04 & .000 \\
\hline $38 / 57$ & $>$ & $37 / 14$ & yes & -5.58 & .000 \\
\hline
\end{tabular}




\subsection{Testing $\mathrm{H} 2_{2}$}

To test $\mathrm{H}_{2}$, a comparison analysis, analogous to that performed in case of the Polish subjects, was carried out. However, the results obtained for the IAS 36 paragraph 12 were not taken into consideration, because, in the English version, the phrase are expected was used instead of the word probable. Table 4 presents the results.

Table 4. Comparison of mean of the level of the probability assigned by the British accounting professionals to the expression probable, resulting in an increase and a decrease in the financial result

\begin{tabular}{|c|c|c|c|c|c|}
\hline \multicolumn{3}{|c|}{$\begin{array}{l}\text { Comparison the average probability assigned } \\
\text { to the expressions used in the IASs }\end{array}$} & \multirow[b]{2}{*}{$\begin{array}{l}\text { Consistency } \\
\text { with our } \\
\text { expectations }\end{array}$} & \multirow[b]{2}{*}{$\mathbf{z}$} & \multirow[b]{2}{*}{$\begin{array}{c}\text { p- } \\
\text { value }\end{array}$} \\
\hline $\begin{array}{c}\text { Resulting in } \\
\text { measurement of the } \\
\text { items increasing the } \\
\text { financial result }\end{array}$ & & $\begin{array}{c}\text { Resulting in } \\
\text { measurement of the } \\
\text { items decreasing the } \\
\text { financial result }\end{array}$ & & & \\
\hline $11 / 23$ & $>$ & $11 / 36$ & no & -2.87 & $<.01$ \\
\hline $12 / 24$ & $>$ & $11 / 36$ & no & -1.76 & .08 \\
\hline $16 / 7$ & $>$ & $11 / 36$ & no & -0.95 & .34 \\
\hline $18 / 22$ & $>$ & $11 / 36$ & no & -1.59 & .11 \\
\hline $38 / 57$ & $>$ & $11 / 36$ & no & -2.07 & $<.05$ \\
\hline $11 / 23$ & $>$ & $37 / 14$ & no & -2.30 & $<.05$ \\
\hline $12 / 24$ & $>$ & $37 / 14$ & no & -1.73 & .08 \\
\hline $16 / 7$ & $>$ & $37 / 14$ & no & -0.97 & .33 \\
\hline $18 / 22$ & $>$ & $37 / 14$ & no & -1.49 & .14 \\
\hline $38 / 57$ & $>$ & $37 / 14$ & no & -2.34 & $<.05$ \\
\hline
\end{tabular}


The results are not as clear as in the case of the Polish subjects. Our observations indicate that, in all ten comparison analyses, the British - contrary to our expectations - assigned a higher level of probability to the items resulting in an increase in the financial result than to the items resulting in a decrease. However, only in 4 cases, these differences were statistically significant. Thus, there are no grounds for a statement that the prudence principle does not affect the level of probability indicated by the British.

\section{Conclusion}

The results show differences in the Polish and the British subjects' interpretation of the VPEs in the IFRS. In five out of the twelve examined IAS excerpts, the Poles designated a significantly lower level of probability to the expressions under examination than the British. With regard to the expression is remote, used in the IAS 37 paragraph 28, the probability assigned by the Poles was significantly higher than that assigned by the British. These findings allowed H1 to be supported partially.

Our analyses also indicate that the Poles assigned a higher level of probability to the items resulting in an increase in the financial result than to the items resulting in its decrease. It is consistent with their attachment to the principle of prudence, even with regards to IFRS-based financial reporting. Thus, it may lead to asymmetrical praxis, in terms of valuation of assets and revenues and/or liabilities and expenses. Contrary to our expectations, the British did not require a lower level of probability assigned to the items resulting in an increase in the financial result than to the items resulting in its decrease. Therefore, we are not in a position to state that the principle of prudence impacts the probability level assigned by the British. It may suggest, that accounting professionals representing the Anglo-Saxon model of accounting may also exhibit behavior associated with application of the prudence principle, however, further studies are required in this area.

The results of our research are in line with those obtained by Doupnik and Richter (2004), Doupnik and Riccio (2006), Chand et al. (2012), Hu et al. (2013) and Huerta et al. (2016). What is more, those authors determined inconsistent interpretation of VPEs, as expressed by respondents from different countries. However, these studies only addressed the US, in comparison to Germany (Doupnik \& Richter, 2004), Brazil (Doupnik \& Riccio, 2006), and Mexico (Huerta et al., 2016). Researchers, such as Chand et al. (2012) and $\mathrm{Hu}$ et al. (2013), also compared China and Australia, whereas Seo and Thomson (2016) contrasted Australia and South Korea. To expand the existing research, we sought such countries, where little research on interpretation of the IFRS has been conducted. Central Eastern European countries - as a region - have been neglected when it comes to this field of study. Thus, our 
study contributes to accounting literature, by providing research that enables understanding of the extent to which the IFRS may be consistently applied across European countries. Awareness of the differences existing in the interpretation of the IFRS facilitates our understanding of the challenges inherent in the ongoing global process of convergence.

The interpretational differences associated with the VPEs in the IFRS may result in inconsistency of the decisions regarding recognition of the items in financial statements, even under the same circumstances and when given the same factual information. This, in turn, limits the international comparability of financial statements (Doupnik \& Riccio, 2006). Thus, the study undertaken by us is extremely relevant, in terms of the standard-setting process, since it might constitute a guideline for the Standard Setters, as to take notice of the use of verbal probability expressions in accounting standards. The inconsistency in application of the same accounting standards, containing particular VPEs, can be limited by removal of those VPEs from the standards (Laswad \& Mak, 1997) or by substitution of those expressions with a suggested probability threshold (Chesley \& Wier, 1985). Neverthelss, the fact of the matter is that elimination or substitution of the VPEs in the IFRS with numerical expressions will not dismiss the necessity of using subjective judgement on the part of the accounting practitioners, which is required in order to specify the probability of occurrence of the events determining recognition of a given item in a financial statement. Such changes, however, could make these judgements more consistent (Jiambalvo \& Wilner, 1985).

The most significant differences observed concerned the interpretation of those VPEs in the IFRS, the Polish translation of which did not truly reflect the original English meaning. An important implication of this study is the fact that the regulators need to pay greater attention to potential translational problems. However, one of the limitations in our study stems from the fact that it did not allow us to state whether the differences observed resulted from the translation (from English into Polish), or from the differences in the understanding of the cores of given words and phrases used by individuals speaking different languages. The need to obtain answers to these questions calls for additional research.

Another limitation of our study that needs to be recognized is the small sample size of the British accounting professionals, which may have limited the generalizability of the results.

\section{Acknowledgements}

This work was supported by the Polish National Science Centre [grant number DEC2012/07/B/HS4/03012]. 


\section{References}

Aharony, J. \& Dotan, A. (2004) "A comparative analysis of auditor, manager and financial analyst interpretations of SFAS 5 disclosure guidelines", Journal of Business Finance and Accounting, vol. 31, no. 3-4: 475-504

Amer, T., Hackenbrack, K. \& Nelson, M. (1994) "Between-auditor differences in the interpretation of probabilities phrases", Auditing. A Journal of Practice and Theory, vol. 3, no. 1: 126-136

Amer, T., Hackenbrack, K. \& Nelson M. (1995) "Context-dependence of auditors' interpretations of the SFAS N. 5 probability expressions", Contemporary Accounting Research, vol. 12, no. 1: 25-39

Baskerville, R. \& Evans, L. (2011) The darkening glass: issues for translation of IFRS, Edinburgh: The Institute of Chartered Accountants of Scotland.

Capriotti, K. \& Waldrup, B.E. (2005) "Miscommunication of uncertainties in financial statements: A study of preparers and users", Journal of Business \& Economics Research, vol. 3, no. 1: 33-46

Carneiro, J., Lima Rodrigues, L. \& Russell C. (2017) "Assessing international accounting harmonization in Latin America", Accounting Forum, vol. 41, no. 3: $172-184$

Chand, P., Cummings, L. \& Patel, C.H. (2012) "The effect of accounting education and national culture on accounting judgments: A comparative study of AngloCeltic and Chinese culture", European Accounting Review, vol. 21, no. 1: 153-182

Chesley, G. (1986) "Interpretation of uncertain expressions", Contemporary Accounting Research, vol. 2, no. 2: 179-199

Chesley, G.R. \& Wier, H.A. (1985) "The challenge of contingencies. Adding precision to probability", CA Magazine, April: 38-41

Copeland, L. \& Griggs, L. (1985) Going international, New York: Random House.

Davidson, R.A. \& Chrisman, H.H. (1993) "Interlinguistic comparison of international accounting standards: the case of uncertainty expressions" International Journal of Accounting, vol. 28, no. 1: 1-16

Doupnik, T. \& Perera, H. (2009) International accounting (2nd ed.), New York: McGraw-Hill.

Doupnik, T. \& Riccio, E. (2006) "The influence of conservatism and secrecy on the interpretation of verbal probability expressions in the Anglo and Latin cultural areas", The International Journal of Accounting, vol. 41: 237-261

Doupnik, T., \& Richter, M. (2003) "Interpretation of uncertain expressions: a crossnational study", Accounting, Organizations and Society, vol. 28: 15-35

Doupnik, T. \& Richter, M. (2004) "The impact of culture on the interpretation of 'in context' verbal probability expressions", Journal of International Accounting Research, vol. 3, no. 1: 1-20 
Evans, L. (2004), "Language, translation and the problem of international accounting communication", Accounting, Auditing \& Accountability Journal, vol. 17, no. 2: 210-248

Ghio, A., Verona, R. (2015) "Accounting harmonization in the BRIC countries: A common path?", Accounting Forum, vol. 39, no. 2: 121-139

Hall, E. T. (1976) Beyond culture, Garden City. NY: Anchor Press.

Hamm, R.M. (1991) "Selection of verbal probabilities: a solution for some problems of verbal probability expression”, Organizational Behaviour and Human Decision Processes, vol. 48, no. 2: 193-223

Han, W., Hellmann, A. \& Lu, M. (2016) "The impact of gender difference on the interpretation of uncertainty expressions", Asian Review of Accounting, vol. 24, no. 2: 185-201

Harrison, K. \& Tomassini, L. (1989) "Judging the probability of a contingent loss: an empirical study", Contemporary Accounting Research, vol. 5, no. 2: 642-648

Helin, A. (2005) Ustawa o rachunkowosci. Komentarz [The Accounting Act. Comments], Warszawa: C. H. Beck.

Hellman, A., Perera, H. \& Patel, Ch. (2010) "Equivalence of IFRS across languages: translation issues rom English to German" available online at pira2010. econ.usyd.edu.au/conference_proceedings/APIRA-2010-198-HellmannEquivalence-of-IFRS-across-languages.pdf /Accessed 21 November 2017.

Hofstede, G. \& Hofstede, G.J. (2007) Kultury i organizacje. Zaprogramowanie umystu [Cultures and organizations: software of the mind], Warszawa: PWE.

Hofstede G., Hofstede G.J. \& Minkov M. (2010) Cultures and organizations: software of the mind (3rd ed.), USA: McGraw-Hill.

Honko, S. (2008) Koncepcja ostroznej wyceny w rachunkowosci [The concept of prudence principle in accounting], Szczecin: Wydawnictwo Naukowe Uniwersytetu Szczecinskiego.

Houghton, K.A. \& Walawski, J.B. (1992) "Asset recognition and probabilistic judgments", Australian Accounting Review, vol. 1, no. 3: 2-9

Hu, C., Chand, P. \& Evans, E. (2013) "The effect of national culture, acculturation, and education on accounting judgments: a comparative study of Australian and Chinese culture", Journal of International Accounting Research, vol. 12, no. 2: 51-77

Huerta, E., Petridesb, Y. \& Braunc, G.P. (2016) "Interpretation of probability expressions in accounting: The effects of frame switching", Journal of International Accounting, Auditing and Taxation, vol. 27: 1-12

Hung, M. \& Subramanyam, K. R. (2007) "Financial statement effects of adopting international accounting standards: the case of Germany", Review of Accounting Studies, vol. 12, no. 4: 623-657

Jaggi, B. \& Low, P. Y. (2000) "Impact of culture, market forces, and legal system on financial disclosure", The International Journal of Accounting, vol. 35, no. 4: 495-519 
Jaruga, A. (1993) "Changing rules of accounting in Poland", European Accounting Review, vol. 2, no. 1: 115-126

Jaruga, A. (2002) "Systemy regulacji rachunkowosci a miedzynarodowa harmonizacja i standaryzacja" [Accounting systems versus International harmonization and standarization] (in) Miedzynarodowe regulacje rachunkowosci, ed. A. Jaruga, Warszawa: C.H. Beck.

Jiambalvo, J. \& Wilner, N. (1985) "Auditor evaluation of contingent claims", Auditing: A Journal of Practice and Theory, vol. 5, no. 1: 1-11

Kabalski, P. (2012) Wybrane problemy stosowania Międzynarodowych Standardow Sprawozdawczosci Finansowej w Polsce. Organizacja, kultura, osobowosc, jezyk [Selected Issues of IFRS Application in Poland. Organization, Culture, Personality, Language], Lodz: Wydawnictwo Uniwersytetu Lodzkiego.

Kabalski, P. \& Szwajcar, J. (2015) "Feminizacja studiow w zakresie rachunkowosci w Polsce - przyczyny i skutki" [Feminization of accounting studies in Poland - causes and consequences], Zeszyty Teoretyczne Rachunkowosci, vol. 81, no. 137: $85-106$

Kosmala, K. (2005) "True and fair view or rzetelny i jasny obraz? A survey of Polish practitioners", European Accounting Review, vol. 14, no. 3: 579-602

Laswad, F. \& Mak, Y. (1997) "Interpretations of probability expressions by New Zealand standard setters", Accounting Horizons, vol. 11, no. 14: 16-23

Lesko, D. (2007) "Polish financial reporting principles in transition", Baltic Journal of Management, vol. 2, no. 1: 55-66

Laughlin, R. \& Gray, R. (1988) Financial Accounting: Method and Meaning, London: Van Nostrand Reinhold (International) Ltd. By: Maltby, J., 2000 "The origins of prudence in accounting", Critical Perspectives On Accounting, vol. 11, no. 1: 51-70

McGlone, M.S. \& Reed, A.B. (1998) "Anchoring in the interpretation of probability expressions", Journal of Pragmatics, vol. 30, no. 6: 723-733

Nelson, M. \& Kinney, W. (1997) "The effect of ambiguity on loss contingency reporting judgements", The Accounting Review, vol. 72, no. 2: 257-274

Nobes, C. (1998) "Towards a general model of the reasons for International differences in Financial Reporting", Abacus, vol. 34, no. 2: 162-187

Nobes, C. (2006) "The survival of international differences under IFRS: towards a research agenda", Accounting and Business Research, vol. 36, no. 3: 233-245

Philips, L.D. (1970) “The 'true probability'problem”, Acta Psychologica, vol. 34: 254-264

Reimers, J. (1992) "Additional evidence on the need for disclosure reform", Accounting Horizons, vol. 6, no. 1: 36-41

Richardson, G. (2007) "The influence of culture on tax systems internationally: A theoretical and empirical analysis", Journal of International Accounting Research, vol. 6, no. 1: 57-79

Roberts, C. B., Weetman, P. \& Gordon, P. D. (2008) International corporate reporting - A comparative approach, Harlow: Financial Times Prentice Hall. 
Salleh, S.I.M., Gardner, J. C., Sulong, Z., Carl, B. \& McGowan, C. B. (2011a) “A comparison of the interpretation of "in context" verbal probability expressions used in International Accounting Standards by the demographic factors of students studying at United Kingdom universities", available on line at http://www.intellectbase.org/e_publications/proceedings/IHART_Summer_2 011.pdf\#page=71/Accessed 31 October 2017.

Salleh, S.I.M., Gardner, J. C., Sulong, Z., Carl, B. \& McGowan, C. B. (2011b) “The interpretation of in context verbal probability expressions used in international accounting standards: a comparison of English and Chinese students studying at english speaking universities", Journal of International Education Research, vol. 7, no. 2: 67-79

Schultz, J. J. \& Lopez, T. J. (2001) "The impact of national influence on accounting estimates: Implications for international accounting standard-setters", The International Journal of Accounting, vol. 36, no. 1: 271-290

Seo, Y. \& Thomson, A. (2016) Accounting judgments on terms of likelihood in IFRS: Korea and Australia, Report published by the Korea Accounting Standards Board and Australian Accounting Standards Board, available on line at http://www.aasb.gov.au/admin/file/content102/c3/July_2016_(KASBAASB)\%20Accounting\%20Judgments\%20on\%20Terms\%20of\%20Likeliho od\%20in\%20IFR....pdf /Accessed 3 December 2018.

Simon, J. (2002) "Interpretation of probability expressions by financial directors and auditors of UK Companies", The European Accounting Review, vol. 11, no. 3: 601-629

Surdykowska, S. (1999) Rachunkowosc miedzynarodowa [International Accounting], Krakow: Zakamycze.

Teixeira, C. \& Silva, A.F. (2009) "The interpretation of verbal probability expressions used in the IAS/IFRS: Some Portuguese evidence", Revista de Estudos Politecnicos Polytehnical Studies Review, vol. 7, no. 12: 57-73

Wallsten, T.S., Fillenbaum, S. \& Cox, J.A. (1986) "Base rate effects on the interpretations of probability and frequency expressions", Journal of Memory and Language, vol. 25, no. 5: 571-587

Watts, R.L. (2002) "Conservatism in accounting", Simon School of Business Working Paper No. FR 02-21, available on-line at https://ssrn.com/ abstract $=371820$.

Wehrfritz, M. \& Haller, A. (2014) "National influence on the application of IFRS: Interpretations and accounting estimates by German and British accountants", Advances in Accounting, incorporating Advances in International Accounting, vol. 30, no. 1: 196-208

Winiarska, K. (2009) Rachunkowosc miedzynarodowa [International Accounting], Gdansk: ODDK.

Wright, G.N., \& Philips, L.D. (1980) "Cultural variation in probabilistic thinking: alternative ways of dealing with uncertainty", International Journal of Psychology, vol. 15, no. 1-4: 239-257 
The Interpretation of the Verbal Probability Expressions Used in the IFRS - The Differences observed between Polish and British Accounting Professionals

Vellam, I. (2004) "Implementation of International Accounting Standards in Poland: Can true convergence be achieved in practice?", Accounting in Europe, vol. 1, no. 1: 143-167

Zieba, A. (2008) "Jezyk a kultura. Komunikacja werbalna w wybranych polskich, brytyjskich i amerykanskich programach telewizyjnych" [Language and culture. Verbal communication in selected Polish, British and American TV programmes], Investigationes Linguisticae, vol. XVI: 250-263, available online at http://www.staff.amu.edu.pl/ inveling/pdf/Anna_Zieba_inve16.pdf / Accessed 7 November 2017.

Zwick, R. (1987) Combining stochastic uncertainty and linguistic inexactness: Theory and experimental evaluation, Ph.D. dissertation, North Carolina: University of North Carolina Chapel Hill. By Hamm, R.M. (1991) "Selection of verbal probabilities: a solution for soma problems of verbal probability expression", Organizational Behaviour and Human Decision Processes, vol. 48: 193-223. 